Int. J. Electrochem. Sci., 13 (2018) $4981-4990$

\title{
Graphitic Carbon Nitride Sputtered with Silver Nanoparticles for Efficient Photocatalytic Degradation of Rhodamine B Dye
}

\author{
Lifeng Cui ${ }^{\dagger}, *$, Tingting Pü, Xueyou Fang ${ }^{\dagger}$, Jialing Song, Shasha Li, Junjie Wang, \\ Chaochuang Yin, Huancong Shi, Shifei Kang \\ Department of Environmental Science and Technology, University of Shanghai for Science and \\ Technology, Shanghai 200093, China \\ $\dagger$ These authors contributed equally to this work and should be considered co-first authors. \\ *E-mail: lifeng.cui@gmail.com
}

doi: $10.20964 / 2018.05 .83$

Received: 31 Janary 2018 / Accepted: 9 March 2018 / Published: 10 April 2018

Graphitic carbon nitride $\left(\mathrm{g}-\mathrm{C}_{3} \mathrm{~N}_{4}\right)$ powder was synthesized using a thermal polymerization method. Silver nanoparticles were uniformly deposited on thin sheets of $g-\mathrm{C}_{3} \mathrm{~N}_{4}$ using a simple sputtering method. Pure $\mathrm{g}-\mathrm{C}_{3} \mathrm{~N}_{4}$ and $\mathrm{Ag} / \mathrm{g}-\mathrm{C}_{3} \mathrm{~N}_{4}$ were tested for photocatalytic degradation performance of Rhodamine $\mathrm{B}$ dye under visible light. The degradation tests show that photocatalytic activity of heterostructured $\mathrm{Ag} / \mathrm{g}-\mathrm{C}_{3} \mathrm{~N}_{4}$ was greatly enhanced compared with that of pure $\mathrm{g}-\mathrm{C}_{3} \mathrm{~N}_{4}$ even with as little as $0.08 \mathrm{wt} \%$ added silver. The percentage of silver used is significantly lower than that used in previous studies of $\mathrm{Ag} / \mathrm{g}-\mathrm{C}_{3} \mathrm{~N}_{4}$ composite catalysts. The $\mathrm{Ag} / \mathrm{g}-\mathrm{C}_{3} \mathrm{~N}_{4}$ catalyst also shows excellent stability over multiple reaction cycles.

Keywords: Photocatalytic degradation, Graphitic carbon nitride, Silver nanoparticles, Sputtering method, Electrochemical impedance spectroscopy.

\section{$\underline{\text { FULL TEXT }}$}

(C) 2018 The Authors. Published by ESG (www.electrochemsci.org). This article is an open access article distributed under the terms and conditions of the Creative Commons Attribution license (http://creativecommons.org/licenses/by/4.0/). 